Reprod. Nutr. Dévelop., 1987, 27 (5), 929-939.

\title{
Effects of wheat bran on exocrine pancreas secretion in the pig
}

\author{
Annik LANGLOIS, T. CORRING, C. FÉVRIER $\left({ }^{*}\right)$
}

Laboratoire de Physiologie de la Nutrition I.N.R.A.-C.R.J., 78350 Jouy-en-Josas, France.

(*) Station de Recherches Porcines, St-Gilles, 35590 L'Hermitage, France.

Summary. The aim of this study was to determine the effect of wheat bran consumption on exocrine pancreas secretion in pigs. Sixteen Large-White pigs were divided into two groups. The first group (control) was fed a diet without wheat bran and the second one (experimental) a diet containing $40 \%$ wheat bran. After one week the animals were fitted with two permanent fistulae (in the pancreatic duct and the duodenum) and/or with a catheter in a carotid artery. After an 8-day recovery period, pancreatic secretion (volume, protein content and output, chymotrypsin, trypsin, lipase and amylase activities) and plasma levels of some gastro-intestinal peptides [secretin, cholecystokinin (CCK), vasoactive intestinal peptide (VIP), somatostatin and pancreatic polypeptide (PP)] were measured over an experimental period of 5 days.

The results show that wheat bran intake induced an increase in the volume $(+115 \%)$ and protein output $(+36 \%)$ of the pancreatic juice secreted in a 24-hour period, whereas protein concentration decreased. All enzyme activities were enhanced by wheat bran. The plasma levels of secretin, VIP, somatostatin and PP were higher in the experimental than in the control group. On the contrary, plasma CCK levels were not affected by wheat bran consumption.

\section{Introduction.}

Dietary fiber is known to decrease the availability of food components (Kass et al., 1980 ; Shah et al., 1982 ; Burrows et al., 1982 ; Kuan, Stanogias and Dukin, 19831 , and the most pronounced effect in the pig was noted with wheat bran (Henry and Perez, 1983). Such a decreasing effect is not well understood and different hypotheses have been proposed : - alteration of intestinal transit time (Burrows et al., 1982 ; Bardon and Fioramonti, 1983), - alteration of small intestine function (Schneeman, Richter and Jacobs, 1982 ; Thomsen and TasmanJones, 1982), - decrease of intestinal pancreatic enzyme hydrolysis due to adsorption of pancreas enzymes (Isaksson, Lundquist and Ihse, 1982) and bile acids (Story and Kritchevsky, 1976) or to a change in exocrine pancreas secretion. Most works on the pancreatic function were done in vitro (Isaksson, Lundquist 
Ihse, 1982 ; Dutta and Hlasko, 1985) or in pancreatic tissue and intestinal contents (Schneeman, Richter and Jacobs, 1982 ; Isaksson, Asp and Ihse, 1983 ; Shah, Mahoney and Pellet, 1986). There are few studies on the effect of dietary fiber on pancreatic production which reaches the intestine where hydrolysis occurs (Fofana et al., 1981 ; Stock-Damge et al., 1983, 1984 ; Ikegami et al., 1984 ; Sofrankova, 1986), and the purpose of the present work was to evaluate the effects of wheat bran consumption on exocrine pancreas secretion in the fistulated pig. Until now, such data were not available in this species. Furthermore, in order to obtain information on the mechanism involved in pancreatic response to dietary fiber, we determined the plasma levels of some peptides regulating exocrine pancreas secretion.

\section{Material and methods.}

Animals and diets. - Sixteen growing, castrated Large-White male pigs were divided into two groups. The first group (control) was fed a diet without wheat bran and the second one (experimental) a diet with $40 \%$ wheat bran. The two diets were isoproteic $(21 \%$ protein) and isocaloric in crude energy $(4400 \mathrm{Kcal} / \mathrm{kg}$ ), the values being different in digestible energy (Février et al., unpublished data). The diet composition is given in table 1 . The feed was

TABLE 1

Composition of diets.

\begin{tabular}{lcc}
\hline & \multicolumn{2}{c}{ Diets } \\
\hline & $\begin{array}{c}\text { Control group } \\
\text { Diet } 0 \%\end{array}$ & $\begin{array}{c}\text { Experimental group } \\
\text { Diet } 40 \%\end{array}$ \\
\hline Component, \% of fresh matter : & & \\
Coarse wheat bran & - & 40 \\
Wheat & 83 & 45 \\
Casein & 5.0 & 4.1 \\
Fish meal & 5.0 & 0.1 \\
Dicalcium phosphate & 1.4 & 1.3 \\
Calcium carbonate & 1.0 & 0.5 \\
Sodium chloride & 0.5 & 4.0 \\
Mineral mix (1) & 4.0 & 0.1 \\
Vitamin mix (2) & 0.1 & \\
Component, \% of dry weight : & & 5.28 \\
Crude fiber & 1.90 & 21.07 \\
Neutral Detergent Fiber & 8.87 & 6.24 \\
Acid Detergent Fiber & 2.70 & 1.31 \\
Lignin & 0.50 & \\
\hline
\end{tabular}

(1) Trace elements in mg/kg diet : IK, $0.8 ; \mathrm{CuSO}_{4}, 5 \mathrm{H}_{2} \mathrm{O}, 20 ; \mathrm{ZnSO}_{4}, \mathrm{H}_{2} \mathrm{O}, 350 ; \mathrm{CoSO}_{4}, 7 \mathrm{H}_{2} \mathrm{O}$, $0.4 ; \mathrm{MnSO}_{4}, \mathrm{H}_{2} \mathrm{O}, 50 ; \mathrm{MgSO}_{4}, 0.4 ; \mathrm{FeSO}_{4}, 7 \mathrm{H}_{2} \mathrm{O}, 50 ; \mathrm{Na}_{2} \mathrm{SeO}_{3}, 0.4$.

(2) In mg/kg diet : vitamin A (500000 l.U./g), 10 ; vitamin $D_{3}(100000$ l.U./g), 10 ; vitamin $E$ (250 I.U./g), 40 ; vitamin $K, 8$; vitamin $B_{1}, 1$; vitamin $B_{2}, 4$; pyridoxine chlorhydrate, 1 ; folic acid, 1 ; vitamin $B_{12}(500 \mathrm{mg} / \mathrm{kg}), 40$; biotin $(1 \mathrm{p}$. 100), 20 ; calcium pantothenate, 10 ; choline, 1000 ; niacine, 15. 
provided in two equal meals of $800 \mathrm{~g}$ each (food/water: 1/2) at 0900 and $1600 \mathrm{~h}$.

Experimental design. - The pigs were adapted to their diets for 8 days before surgery. In each group of 8, 5 pigs were fitted with two permanent fistulae, one in the pancreatic duct and the other in the duodenum, according to Corring, Aumaitre and Rérat (1972), at a mean liveweight of $38 \pm 1.7 \mathrm{~kg}$ for the control group and $38 \pm 1.1 \mathrm{~kg}$ for the experimental group. Two of the 5 pigs fistulated in the pancreatic duct were also fitted with a catheter in a carotid artery. The other pigs ( 3 control and 3 experimental) were only fitted with a fistula in a carotid artery.

After surgery they were put into individual metabolism-type cages and fed their diets during an 8-day recovery period and a 5-day experimental period.

Measurement of pancreatic secretion. - The catheters for pancreatic juice secretion and return were connected to an apparatus which immediately reintroduced the secreted pancreatic juice into the duodenum and automatically gave a precise record of its volume (Juste, Corring and Le Coz, 1983). During the recovery period, the pancreatic juice was entirely reintroduced into the duodenum, and a sample of the secreted juice $(4 \%)$ was continuously withdrawn for analysis during the experimental period.

The hourly samples were pooled in five periods according to the level of pancreatic protein secretion : postprandial secretions from 0900 to $1300 \mathrm{~h}$ and from 1600 to $2000 \mathrm{~h}$; interdigestive state from 1300 to $1600 \mathrm{~h}$ and basal secretions from 2000 to $0200 \mathrm{~h}$ and from 0200 to $0900 \mathrm{~h}$. The samples were stored at $-80^{\circ} \mathrm{C}$ until analysis.

Arterial blood sampling. - The catheter in the carotid artery was used to sample arterial blood at 0845,1200 and $1530 \mathrm{~h}$ on each day of the experimental period. These times were chosen according to the level of pancreatic enzyme secretion which was basal at $0845 \mathrm{~h}$, stimulated by food intake at $1200 \mathrm{~h}$ and low at $1530 \mathrm{~h}$. Ten $\mathrm{ml}$ of blood were collected in ice-chilled tubes containing 10 units of heparin and 500 units of trasylol aprotinin per $\mathrm{ml}$ of blood. After centrifugation, plasma aliquots were stored at $-20^{\circ} \mathrm{C}$ until assay of the regulatory peptides.

\section{Analysis}

- Pancreatic juice. - Total proteins and lipase, amylase, trypsin and chymotrypsin activities were determined in all samples. Total proteins were determined according to Lowry et al. (1951). Lipase activity was measured by titrimetry at $\mathrm{pH} 9$ according to the method of Rathelot et al. (1975). Amylase activity was determined accoding to the modified method of Metais and Bieth (1968) on a biological sample containing high amylase activity (Corring and Saucier, 1972). Chymotrypsin and trypsin activities were measured by titrimetry on ATEE and BAEE substrates, respectively, after proenzyme activation (Reboud, Ben Abdeljlil and Desnuelle, 1962).

- Hormone radioimmunoassays. - Immunoreactive secretin, cholecystokinin (CCK), vasoactive intestinal peptide (VIP), somatostatin and pancreatic polypeptide (PP) were measured in the arterial plasma, according to previously repor- 
ted methods (Pelletier, Chayvialle and Minaire, 1978 : Chavvialle et al., 1978 ; Corring, Gueugneau and Chayvialle, 1986).

Statistical analysis. - The data were analysed by conventional least-squares analysis for a completely random design. Individual-treatment mean comparisons were tested by multiple-range techniques (Dagnelie, 1970). The statistical difference between two means was accepted when $\mathrm{P}<0.05$.

\section{Results.}

During the post-operative period (15 days), animal growth was $550 \pm 170 \mathrm{~g} /$ day in the control group and $400 \pm 38 \mathrm{~g} /$ day in the experimental one.

Pancreatic juice. - The daily protein output in the pancreatic juice was significantly higher in the experimental than in the control group (19 748 vs $14540 \mathrm{mg}$; $P<0.05$ ) (fig. 1). This increase was mainly due to an enhancement of the volume ( 3585 vs $1668 \mathrm{ml} ; \mathrm{P}<0.05$ ). The total protein concentration of the pancreatic juice secreted per $24 \mathrm{~h}$ was lower in pigs fed wheat bran $(5.6 \mathrm{vs}$ $9.7 \mathrm{mg} / \mathrm{ml} ; \mathrm{P}<0.05$ ) (fig. 1).

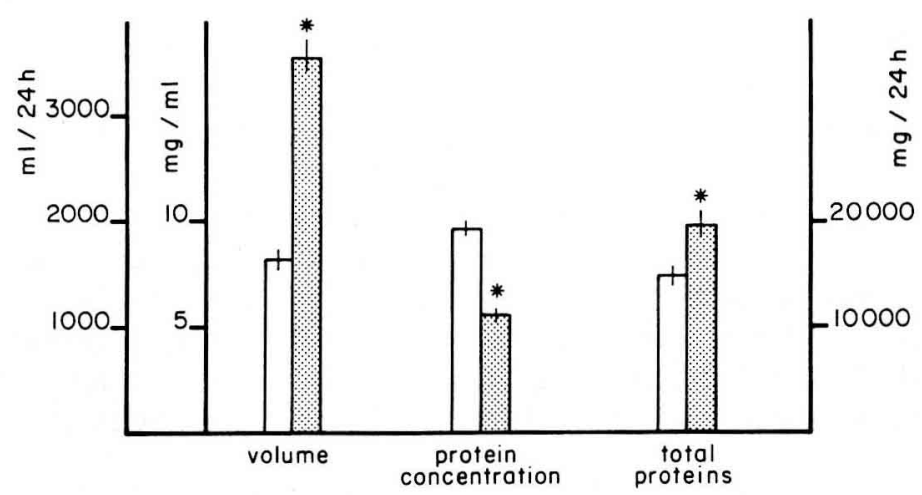

F'G. 1. - Effects of wheat bran consumption on volume $(\mathrm{ml})$, protein concentration $(\mathrm{mg} / \mathrm{ml})$ and total proteins $(\mathrm{mg})$ secreted per $24 \mathrm{~h}$ in pancreatic juice.

$\square$ Control group (M \pm SEM ; 25 experimental days; 5 pigs); $:$ Experimental group (M \pm SEM ; 22 experimental days ; 5 pigs) * $\mathrm{P}<0.05$.

Examination of the hourly volumes clearly indicated that pancreatic volume was higher at all times of the day in pigs fed the experimental diet than in those fed the control diet (fig. 2). The decrease in protein concentration was significant except for the second basal period $(0200$ to $0900 \mathrm{~h})$, and the increase in protein output became significant from $1600 \mathrm{~h}$ (table 2). Daily enzymatic activities (fig. 3) were significantly higher in the experimental group and these increases were seen at all times of the day. 


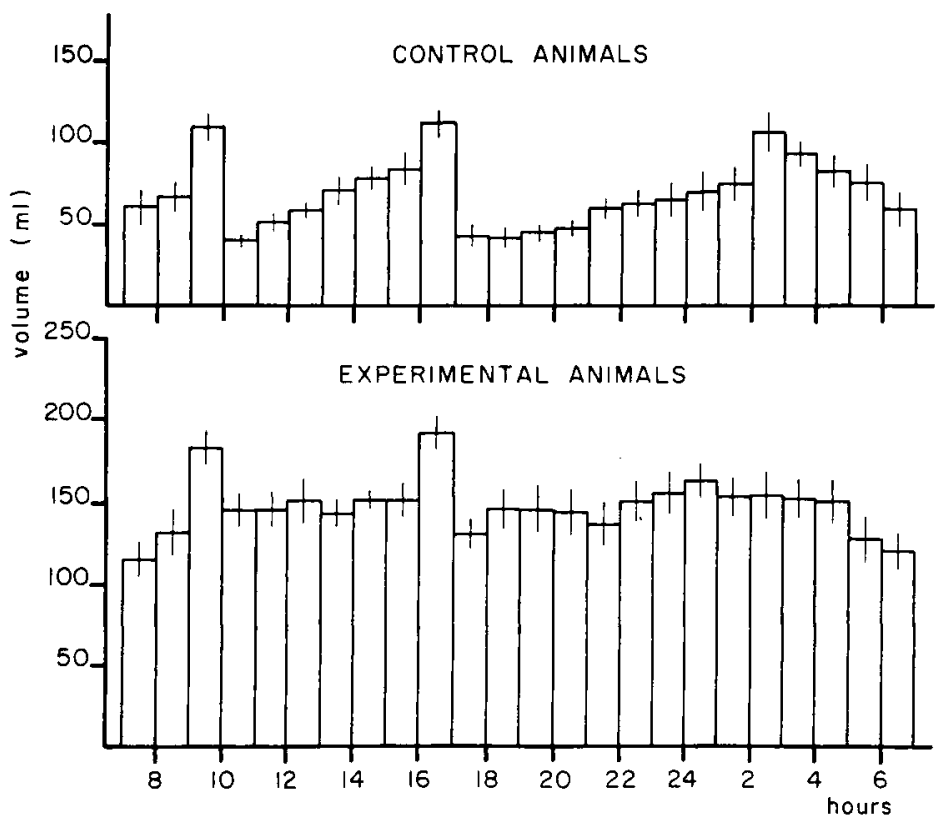

FIG. 2. - Effects of wheat bran consumption on the volume of pancreatic juice secreted per 24 hours.

TABLE 2

Effects of wheat bran consumption on the volume $(\mathrm{ml} /$ period), protein concentration $(\mathrm{mg} / \mathrm{ml} /$ period) and total proteins $(\mathrm{mg} / \mathrm{period})$ of exocrine pancreas secretion in pigs (1).

\begin{tabular}{|c|c|c|c|c|c|c|}
\hline & \multicolumn{2}{|c|}{ Volume } & \multicolumn{2}{|c|}{ Protein concentration } & \multicolumn{2}{|c|}{ Total proteins } \\
\hline & \multicolumn{2}{|c|}{ Diet } & \multicolumn{2}{|c|}{ Diet } & \multicolumn{2}{|c|}{ Diet } \\
\hline & $0 \%$ & $40 \%$ & $0 \%$ & $40 \%$ & $0 \%$ & $40 \%$ \\
\hline $\begin{array}{l}\text { Period } 1 \text { (2) } \\
\text { Period } 2 \\
\text { Period } 3 \\
\text { Period } 4 \\
\text { Period } 5\end{array}$ & $\begin{array}{l}270 \pm 14(3) \\
242 \pm 21 \\
244 \pm 19 \\
388 \pm 41 \\
533 \pm 41\end{array}$ & $\begin{array}{l}628 \pm 58^{*} \\
442 \pm 19^{*} \\
619 \pm 27^{*} \\
919 \pm 55^{*} \\
970 \pm 61^{*}\end{array}$ & $\begin{array}{r}14.5 \pm 0.7 \\
9.2 \pm 0.4 \\
12.1 \pm 0.6 \\
8.2 \pm 0.5 \\
5.2 \pm 0.4\end{array}$ & $\begin{array}{l}6.2 \pm 0.3^{*} \\
5.3 \pm 0.3^{*} \\
6.5 \pm 0.3^{*} \\
5.2 \pm 0.2^{*} \\
4.6 \pm 0.2\end{array}$ & $\begin{array}{l}3823 \pm 247 \\
2169 \pm 199 \\
2891 \pm 231 \\
2960 \pm 311 \\
2726 \pm 288\end{array}$ & $\begin{array}{l}3913 \pm 331 \\
2387 \pm 182 \\
4114 \pm 337^{*} \\
4840 \pm 365^{*} \\
4494 \pm 351^{*}\end{array}$ \\
\hline
\end{tabular}

(1) Diet $0 \%$ (25 experimental days, 5 pigs) ; Diet $40 \%$ (22 experimental days, 5 pigs).

(2) Period 1:0900 to $1300 \mathrm{~h}$; Period 2: 1300 to $1600 \mathrm{~h}$; Period 3: 1600 to $2000 \mathrm{~h}$; Periode $4: 2000$ to $0200 \mathrm{~h}$; Period $5: 0200$ to $0900 \mathrm{~h}$.

(3) $M \pm$ SEM.

${ }^{*} P<0.05$. 
Regulatory peptides. - Feeding the wheat bran diet induced an increase in plasma levels of secretin and VIP (table 3) and these increases were significant except for secretin at $0845 \mathrm{~h}$.

Plasma levels of somatostatin and PP were higher in the experimental group. The difference between the two groups became significant at 1200 and $1530 \mathrm{~h}$ for somatostatin and at 0845 and $1530 \mathrm{~h}$ for PP levels (table 3 ).

On the contrary, plasma CCK levels were not affected by wheat bran consumption, whatever the time of blood collection (table 3 ).

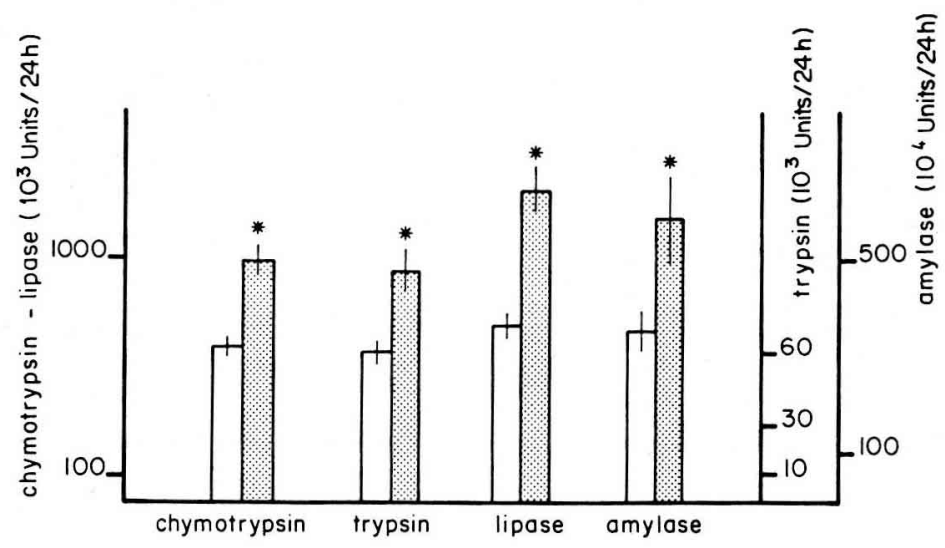

FIG. 3. - Effects of wheat bran consumption on pancreatic activities (Units/24 hours) of chymotrypsin, trypsin, lipase and amylase.

$\square$ Control group (M \pm SEM ; 25 experimental days ; 5 pigs); $: 0$ Experimental group ( $M \pm S E M ; 22$ experimental days ; 5 pigs) $* P<0.05$.

TABLE 3

Effects of wheat bran consumption on plasma leve/s ${ }^{(1)}(\mathrm{pg} / \mathrm{ml})$ of secretin, cholecystokinin (CCK), pancreatic polypeptide (PP), somatostatin and vasoactive intestinal peptide (VIP), in pigs.

\begin{tabular}{|c|c|c|c|c|c|c|}
\hline & \multicolumn{2}{|c|}{$0845 \mathrm{~h}$} & \multicolumn{2}{|c|}{$12 \mathrm{~h}$} & \multicolumn{2}{|c|}{$1530 \mathrm{~h}$} \\
\hline & \multicolumn{2}{|c|}{ Diet } & \multicolumn{2}{|c|}{ Diet } & \multicolumn{2}{|c|}{ Diet } \\
\hline & $0 \%$ & $40 \%$ & $0 \%$ & $40 \%$ & $0 \%$ & $40 \%$ \\
\hline $\begin{array}{l}\text { Secretin } \\
\text { CCK } \\
\text { PP } \\
\text { Somatostatin } \\
\text { VIP }\end{array}$ & $\begin{array}{l}19.4 \pm 1.2(2) \\
14.8 \pm 0.8 \\
165 \pm 21 \\
45.5 \pm 3.6 \\
16.0 \pm 1.3\end{array}$ & $\begin{array}{l}25.1 \pm 2.6 \\
14.6 \pm 0.7 \\
317 \pm 38^{*} \\
50.4 \pm 3.5 \\
23.9 \pm 3.2^{*}\end{array}$ & $\begin{array}{l}19.3 \pm 1.3 \\
20.5 \pm 1.3 \\
462 \pm 38 \\
57.2 \pm 4.3 \\
15.2 \pm 1.1\end{array}$ & $\begin{array}{l}30.4 \pm 2.9^{*} \\
17.7 \pm 1.1 \\
514 \pm 36 \\
72.8 \pm 5.2^{*} \\
24.8 \pm 3.3^{*}\end{array}$ & $\begin{array}{l}18.9 \pm 1.2 \\
15.9 \pm 0.8 \\
195 \pm 18 \\
49.7 \pm 3.3 \\
15.9 \pm 1.1\end{array}$ & $\begin{array}{l}29.7 \pm 2.2^{*} \\
16.6 \pm 1.0 \\
328 \pm 28^{*} \\
58.9 \pm 3.0^{*} \\
25.3 \pm 2.9^{*}\end{array}$ \\
\hline
\end{tabular}

(1) Diet $0 \%$ (25 experimental days, 5 pigs) ; Diet $40 \%$ (22 experimental days, 5 pigs).

(2) $M \pm S E M$.

${ }^{*} P<0.05$. 


\section{Discussion}

In the present work, we have described the effects of the consumption of a dietary fiber on exocrine pancreas secretion in the conscious pig normally fed, without any exogenous stimulation of secretion. Animal growth in both the control and experimental groups can be considered as quite normal after surgery since it was similar to that observed in the pigs before fistulation.

Daily protein secretion was divided into five time-periods, two of them corresponding to pancreatic response to meal consumption and thus to stimulated secretion. Protein basal secretion was observed in the other three periods, namely during the night.

In pigs adapted to a wheat bran-rich diet, total pancreatic protein production per $24 \mathrm{~h}$ was increased by $36 \%$. This increase resulted mainly from an augmentation $(+115 \%)$ of juice volume and probably from enhancement of pancreatic protein biosynthesis. The volume was elevated at all times of the day, during stimulation as well as during basal secretion. Stock-Damge et al. (1983, 1984) studying the dog also reported a significant stimulatory effect on volume and total protein production of basal pancreatic secretion (fasted animals) or of stimulated secretion (intravenous perfusion of secretin alone or of secretin + caerulein) when the animal was adapted to wheat bran intake. In fistulated rats fed wheat bran for 3 weeks, Fofana et al. (1981) observed a slight increase in pancreatic enzyme production stimulated with 2-deoxyglucose, while juice volume was not affected. In the same species, Sommer and Kasper (1984) showed that the addition of wheat bran to a fiber-free diet for 6 weeks caused an increase in bicarbonate production when pancreatic secretion was stimulated with secretin and $\mathrm{CCK}$, the basal secretion being unchanged.

Pancreatic juice volume per $24 \mathrm{~h}$ in the control pigs showed a short, high increase in the first hour after meal consumption, followed by a decrease and then by a progressive increase. This observation confirms data obtained in more than 50 pigs fed a normal standard feed (Corring, unpublished data). On the contrary, such a biphasic response to meal consumption rate was not observed in the experimental animals. Secretion volume seemed to be stimulated by wheat bran to such an extent that the effect of the meal was not evident.

Total activities increased in pigs fed wheat bran: trypsin, $+58 \%$; chymotrypsin, $+59 \%$; amylase, $+70 \%$; lipase, $+78 \%$. Stock-Damge et al. $(1983,1984)$ also reported increased activities of amylase and chymotrypsin but decreased activity of lipase in the pancreatic juice of dogs fed wheat bran. Wheat bran intake does seem to affect pancreatic enzyme production in pigs but does not induce any decrease in enzyme activity as in dogs. The low digestibility of the diet containing wheat bran (Kass et al., 1980 ; Henry and Perez, 1983) could thus be explained by the alteration of another digestive step. According to Schneeman, Richter and Jacobs (1982), pancreatic enzyme activities in intestinal contents are decreased in rats fed a diet containing $20 \%$ cellulose. In humans, a bran-rich wheat diet induced a decrease in the total activities of lipase, amylase and trypsin in the duodenal contents (Isaksson et al., 1982). In these cases, wheat bran would exert an inhibitory effect on pancreatic enzymes; such an effect has 
been shown in vitro by many authors (Isaksson, Lundquist and Ishe, 1982 ; Dutta and Hlasko, 1985). On the other hand, decreased enzyme activities could also be explained by the acceleration of the gastrointestinal transit induced by wheat bran (Burrows et al., 1982 ; Bardon and Fioramonti, 1983).

The mechanism involved in the augmentation of juice volume, observed in the pigs fed wheat bran, has to be elucidated. A similar increase in volume was reported in pigs fed raw soyabean containing proteolytic enzyme inhibitors (Corring, Gueugneau and Chayvialle, 1986), and Mitsunaga (1974) and Hansen and Schulz (1982) showed that wheat bran also contains proteolytic and amylase enzyme inhibitors. The volume increase observed in the present study might be partly due to the presence of enzyme inhibitors in the diet. Furthermore, it was reported (Corring, Gueugneau and Chayvialle, 1986) that pancreatic response to raw soyabean caused the release of peptides regulating pancreatic secretion, namely secretin.

In the present work, the plasma level of some peptides was determined. If these measurements cannot explain all the variations of pancreatic secretion of pigs fed wheat bran, a few relationships between pancreatic volume and peptide changes are evident. There was an increase in juice volume between 0800 and $0900 \mathrm{~h}(123 \pm 13$ vs $66 \pm 9 \mathrm{ml}), 1200$ and $1300 \mathrm{~h}(138 \pm 14$ vs $59 \pm 4 \mathrm{ml})$ and 1500 and $1600 \mathrm{~h}(143 \pm 14$ vs $84 \pm 10 \mathrm{ml})$, and an increase in the plasma levels of secretin and VIP at 0845,1200 and $1530 \mathrm{~h}$ in pigs fed wheat bran. Secretin and VIP are known to stimulate the volume of exocrine pancreas secretion in pigs (Jensen et al., 1978 ; Schaffalitzky et al., 1979). We also noted an increase in the plasma levels of PP and somatostatin, peptides known to inhibit the volume of pancreatic secretion in dogs (Konturek et al., 1982, 1985). Such an effect in pigs does not seem to be due to somatostatin ; this agrees with results obtained by Bloom, Joffe and Polak (1975) and by Fahrenkrug et al. (1979). Concerning PP, Konturek et al. (1982) did not observe any inhibitory effect on the volume of pancreatic secretion when human PP was perfused in men.

Pancreatic protein output was not affected by wheat bran consumption during period $1(0900-1300 \mathrm{~h})$ and period $2(1300-1600 \mathrm{~h})$ but the protein content in the juice decreased in the meantime. This decrease can be explained by both the absence of variation in the plasma level of CCK (known to increase pancreatic protein concentration and protein output in pigs : Jensen et al., 1981) as well as by the increase in the plasma level of PP, known to inhibit pancreatic protein secretion in many species (Lin et al., 1977 ; Konturek et al., 1982 ; Louie, William and Owyang, 1985).

In conclusion, the daily production of pancreatic proteins in pigs adapted to a wheat bran-rich diet was decreased, probably due to an enhancement of pancreatic enzyme biosynthesis, but mainly to an augmentation in juice volume. The latter would result from a change in the plasma profile of peptides regulating pancreatic secretion, namely of secretin and VIP. 
Acknowledgements. - The authors wish to thank Anne Marie Gueugneau, Catherine Philippe, Florence Levenez and T. Gibard for their valuable technical assistance and Georgette Brachet and F. Cointepas for animal care. This work was supported by ATP $1984, N^{\circ} 4400$, "Digestive utilization of plant cell wall material by the different animal species " of the "Institut National de la Recherche Agronomique ", France.

Résumé. Effets de la consommation de son de blé sur la sécrétion pancréatique exocrine chez le porc.

Le but de ce travail était de déterminer, chez le porc, les effets de la consommation d'un régime enrichi en son de blé sur la sécrétion pancréatique exocrine. Deux groupes de 8 porcs chacun, de race Large White, ont été utilisés. Le premier groupe a été nourri avec un régime sans son de blé (témoin) et le second avec un régime contenant $\mathbf{4 0} \%$ de son de blé (expérimental). Après 1 semaine d'adaptation, les animaux ont été munis de fistules permanentes du canal pancréatique et du duodénum et/ou d'un cathéter dans une artère carotide. Après 8 jours de récupération postopératoire, le volume, la concentration et la production de protéines et les activités enzymatiques de la chymotrypsine, de la trypsine, de la lipase et de l'amylase du suc pancréatique ainsi que les concentrations plasmatiques de certains peptides intestinaux (sécrétine, CCK, VIP, somatostatine et PP) ont été déterminés durant une période expérimentale de 5 jours.

Les résultats montrent que la consommation de son de blé a provoqué une augmentation de la production de protéines $(+36 \%)$ et du volume $(+115 \%)$ de suc pancréatique sécrété par $24 \mathrm{~h}$, alors que la concentration protéique était diminuée. Toutes les activités enzymatiques ont été elles aussi augmentées par la consommation de son de blé. Les concentrations plasmatiques de la sécrétine, du VIP, de la somatostatine et du PP étaient plus élevées chez les animaux consommant le régime expérimental alors que les concentrations plasmatiques de CCK n'ont pas été modifiées.

\section{Références}

BARDON T., FIORAMONTI J., 1983. Nature of the effects of bran on digestive transit time in pigs. Br. J. Nutr., 50, 685-690.

BLOOM S. R., JOFFE S. N., POLAK J. M., 1975. Effect of somatostatin on pancreatic and biliary function. Gut, 16, 836-837.

BURROWS C. F., KRONFELD D. S., BANTA C. A., MERRITT A. M., 1982. Effect of fiber on digestibility and transit time in dogs. J. Nutr., 112, 1726-1732.

ChaYvialle J. A., DESCOS F., BERNARD C., MARTIN A., BARBe C., PARTENSKY C., 1978. Somatostatin in mucosa of stomach and duodenum in gastroduodenal disease. Gastroenterology, 75, 13-19.

CORRING T., SAUCIER R., 1972. Sécrétion pancréatique sur porc fistulé. Adaptation à la teneur en protéines du régime. Ann. Biol. anim. Bioch. Biophys., 12, 233-241.

CORRING T., AUMAITRE A., RÉRAT A., 1972. Fistulation permanente du pancréas exocrine chez le porc. Application : réponse de la sécrétion pancréatique au repas. Ann. Biol. anim. Bioch. Biophys., 12, 109-124.

CORRING T., GUEUGNEAU A. M., CHAYVIALLE J. A., 1986. Short-term (8-day) effects of raw soybean diet on exocrine pancreatic secretion and plasma gastrointestinal hormone levels in the pig. Reprod. Nutr. Dévelop., 26, 147-158.

DAGNELIE P., 1970. Les comparaisons multiples de moyennes. In DUCULOT J., éd. Théorie et méthodes statistiques. Applications agronomiques. Vol. II. Presses agronomiques, Gembloux, Belgium, pp. 241-261.

DUTTA S. K., HLASKO J., 1985. Dietary fiber in pancreatic disease : Effect of high fiber diet on fat malabsorption in pancreatic insufficiency and in vitro study of interaction of dietary fiber with pancreatic enzymes. Am. J. clin. Nutr., 41, 517-525. 
FAHRENKRUG J., SCHAFFALITZKY de MUCKADELL B. O., HOLST J. J., JENSEN S. L., 1979. Vasoactive intestinal peptide in vagally mediated pancreatic secretion of fluid and $\mathrm{HCO}_{3} . \mathrm{Am}$. J. Physiol. Endocrinol. Metab. gastrointest. Physiol., 6, E535-E540.

FOFANA M., CHARIOT J., SOUCHARD M., ROZÉ C., 1981. Influence du son sur le pancréas exocrine chez le rat. Reprod. Nutr. Dévelop., 21, 810.

HANSEN W. E., SCHULZ G., 1982. Demonstration of four $\alpha$-amylase inhibitors in wheat bran. Digestion, 25, 36-37 (abstr.).

HENRY Y., PEREZ J. M., 1983. Les systèmes d'évaluation de l'énergie dans l'alimentation du porc. Dossiers Elev., 5 (2), 49-64.

IKEGAMI S., HARADA H., TSUCHIHASHI N., NAGAYAMA S., NISHIDE E., INNAMI S., 1984. Effect of indigestible polysaccharide on pancreatic secretion and biliary output. J. nutr. Sci. Vitaminol., 30, 515-523.

ISAKSSON G., LUNDQUIST I., AKESSON B., IHSE I., 1982. Influence of dietary fiber on intestinal activities of pancreatic enzymes and on fat absorption in man. Digestion, 25, 39 (abstr.).

ISAKSSON G., LUNDQUIST I., IHSE I., 1982. Effect of dietary fiber on pancreatic enzyme activity in vitro. Importance of viscosity, $\mathrm{pH}$, ionic strength, adsorption and time of incubation. Gastroenterology, 82, 918-924.

ISAKSSON G., ASP N. G., IHSE I., 1983. Effects of dietary fiber on pancreatic enzyme activities of ileostomy evacuates and of excretion of fat and nitrogen in the rat. Scand. J. Gastroenterol., 18, 417-423.

JENSEN S. L., FAHRENKRUG J., HOLST J. J., NIELSEN O. V., SCHAFFALITZKY de MUCKADELL O. B., 1978. Secretory effect of V.I.P. on isolated perfused porcine pancreas. Am. J. Physiol., 235, E387-E391.

JENSEN S. L., HOLST J. J., NIELSEN O. V., REHFELD J. F., 1981. Effect of sulfatation of CCK-8 on its stimulation of the endocrine and the exocrine secretion from the isolated perfused porcine pancreas. Digestion, 22, 305-309.

JUSTE C., CORRING T., LE COZ Y., 1983. Bile restitution procedure for studying bile secretion in fistulated pigs. Lab. anim. Sci., 33, 199-202.

KASS M. L., VAN SOEST P. J., POND W. G., LEWIS B., McDOWELL R. E., 1980. Utilization of dietary fiber from alfalfa by growing swine. I. Apparent digestibility of diet componements in specific segments of the gastrointestinal tract. J. anim. Sci, 50, 175-191.

KONTUREK S. J., MEYERS C. A., KWIECEN N., OBTULOWICS W., TASLER J., OLESSKY J., KOPP B., COY D. H., SCHALLY A. V., 1982. Effect of human pancreatic polypeptide and its $\mathrm{C}$-terminal hexapeptide on pancreatic secretion in man and in the dog. Scand. J. Gastroenterol., 17, 395-399.

KONTUREK S. J., CIESZKOWSKY M., BILSKI J., KONTUREK J., BIELANSKI W., SCHALLY A. V., 1985. Effect of cyclic hexapeptide analog of somatostatin on pancreatic secretion in dogs (41985). Proc. Soc. exp. Biol. Med., 178, 68-72.

KUAN K. K., STANOGIAS G., DUNKIN A. C., 1983. The effect of proportion of cell-wall material from luzerne leaf meal on apparent digestibility, rate of passage and gut characteristics in pigs. Anim. Prod., 36, 201-209.

LIN T. M., EVANS D. C., CHANCE R. E., SPRAY G. F., 1977. Bovine pancreatic polypeptide : action on gastric and pancreatic secretions in dogs. Am. J. Physiol. Endocrinol. Metab. gastrointest. Physiol., 1, E311-E315.

LOUIE D. S., WILLIAM J. A., OWYANG C., 1985. Action of pancreatic polypeptide on rat pancreatic secretion : in vivo and in vitro. Am. J. Physiol. gastrointest. liver Physiol., 12, G489-G495.

LOWRY O. H., ROSEBROUGH N. S., FARR A. L., RANDALL R. M., 1951. Protein measurement with the Folin phenol reagent. J. biol. Chem., 26, 265-275.

METAIS P., BIETH J., 1968. Détermination de I' $\alpha$-amylase par une micro-technique. Ann. Biol. clin., 26, 133-142.

MITSUNAGA T., 1974. Some properties of protease inhibitors in wheat grain. J. nutr. Sci. Vitaminol., 20, 153-159.

PELLETIER M. J., CHAYVIALLE J. A., MINAIRE Y., 1978. Uneven and transient secretin release after a liquid test meal. Gastroenterology, $75,1124-1132$. 
RATHELOT J., JULIEN R., CANIONI P., COEROLL C., SARDA L., 1975. Studies on the effect of bile salt and colipase on enzymatic lipolysis. Improved method for the determination of pancreatic lipase and colipase. Biochimie, 57, 1117-1122.

REBOUD J. P., BEN ABDELJIL A., DESNUELLE P., 1962. Variation de la teneur en enzymes du pancréas de rat en fonction de la composition des régimes. Biochim. Biophys. Acta, 58, 326337.

SCHAFFALITZKY de MUCKADELL O. B., FAHRENKRUG J., MATZEN P., RUNE S. J., WORNING H., 1979. Physiological significance of secretin in the pancreatic bicarbonate secretion. II. Pancreatic bicarbonate response to a physiological increase in plasma secretin concentration. Scand. J. Gastroenterol., 14, 85-90.

SCHNEEMAN B. O., RICHTER B. D., JACOBS L. R., 1982. Response to dietary wheat bran in the exocrine pancreas and intestine of rats. $J$. Nutr., 112, 283-286.

SHAH N., ATALLAH M. T., MAHONEY R. R., PELLETT P. L., 1982. Effect of dietary fiber components on fecal nitrogen excretion and protein utilization in growing rats. J. Nutr., 112, 658-666.

SHAH N., MAHONEY R. R., PELLET P. L., 1986. Effect of guar gum, lignin and pectin on proteolytic enzyme levels in the gastrointestinal tract of the rat: A time-based study. $J$. Nutr., 116, 786-794.

SOFRANKOVA A., 1986. Effect of pectin on the function of the rat exocrine pancreas. Phys. Bohemos/ov, 35, 281-284.

SOMMER H., KASPER H., 1984. Effect of long term administration of dietary fiber on the exocrine pancreas of the rat. Hepato-gastroenterol., 31, 176-179.

STOCK-DAMGE C., BOUCHET P., DENTIGER A., APRAHAMIAN M., GRENIER J., 1983. Effect of dietary fiber supplementation on the secretory function of the exocrine pancreas in the dog. Am. J. clin. Nutr., 38, 843-848.

STOCK-DAMGE C., APRAHAMIAN M., RAUL F., HUMBERT W., BOUCHET P., 1984. Effects of wheat bran on the exocrine pancreas and the small mucosa in the dog. J. Nutr., 114, 1076-1082.

STORY J. A., KRITCHEVSKY D., 1976. Comparison of the binding of various bile acids and bile salts in vitro by several type of fiber. J. Nutr., 106, 1292-1294.

THOMSEN L. L., TASMAN-JONES C., 1982. Dissacharidase levels of the rat jejunum are altered by dietary fibre. Digestion, 23, 253-258. 